\title{
The Effect of Problem Solving Learning Method towards Indonesian Subject
} Learners' Learning Outcomes

\author{
Mela Sundari \\ Institut Agama Islam Negeri Bengkulu \\ sundarimela66@gmail.com \\ Suhirman \\ Institut Agama Islam Negeri Bengkulu \\ suhirmn@gmail.com \\ Heny Friantary \\ Institut Agama Islam Negeri Bengkulu \\ Henyfriantary30@gmail.com
}

\begin{abstract}
This study was aimed to reveal the effect of problem solving method on the students' Indonesian subject learning outcomes in the second grade students of IPA Class of SMA Negeri 5 Lebong. This study was designed by using a quantitative approach implementing a quasi experimental method. This method allowed the researchers to study a control class and an experimental class, but the control class did not have a crucial function to control the external variables which influenced the implementation of the experiment. Based on the result of this research, it could be concluded that there was the effect of problem solving on the Indonesian learners' learning outcomes at the second grade students of IPA Class of SMA Negeri 5 Lebong. It triumphantly revealed that there was the influential effect of the implementation of the problem solving learning method. It could be seen that $t_{\text {hitung }}=7,947>t_{\text {tabel }}=2,048$ with the significance level $0,05 \%$. The alternative hypothesis proved that the effect of problem solving on the Indonesian learners' learning outcomes at the second grade students of IPA Class of SMA Negeri 5 Lebong was acceptable.
\end{abstract}

Keywords: Problem Solving Method, Learning Outcome, Indonesian Language Education

\section{A. Introduction}

Education can be defined as one of the best ways to create a great civilization. It is intended as the crucial alternative to develop Indonesian for better individuals physically and mentally. In this case, the Indonesian government has been struggling to improve the people's quality development through the 
Jadila: Journal of Development and Innovation

E-ISSN: 2723-6900

in Language and Literature Education

P-ISSN: 2745-9578

Publisher: Yayasan Karinosseff Muda Indonesia

Volume 2 Number 4

Page 423-437

implementation of formal education in schools. There are various kinds of learning methods. A good teacher must master these methods which are appropriate for their class. The most common method used by teachers is the conventional method. This conventional method has weaknesses, for instance the learning process is unidirectional or students only act passively. The unidirectional learning process is that there is no interaction between teachers and students, the learning process just focuses on the teacher while the students are only allowed to listen.

Furthermore, there are several problems that can cause the teaching and learning process to be unsuccessful. One of them is students' learning interests. In this case, students have low interest and motivation in the Indonesian learning process as it is known that Indonesian language learning is learning that requires reasoning so that students' thinking patterns on the problems to be solved are very necessary and crucial. The other problem that also often occurs during the learning activities is that students do not understand the material given by the teacher. Thus, when the teacher explains the learning material, they do not really pay their attention well. If such cases are conducted continuously, they can affect the success of student learning. Therefore, the teachers should implement various learning activities in the learning process.

Learning activities can be said to be successful if every teacher is able to deliver their learning materials to the students properly. They should have various ways to make learning activities successful depending on what method they use. Therefore, if one of the learning methods is not able to increase the learning outcomes in accordance with the KKM (Minimum Completeness Criteria), the teachers can use the other methods. In this case, creativity of the teachers is really needed since the teaching and learning activities should be guided by the curriculum in the school.

The implemented curriculum also affects the learning methods used by teachers. The curriculum used at SMA Negeri 5 Lebong is: 2013 curriculum or commonly called k-13. The curriculum has several aspects of assessment, namely 
Jadila: Journal of Development and Innovation

E-ISSN: 2723-6900

in Language and Literature Education

P-ISSN: 2745-9578

Publisher: Yayasan Karinosseff Muda Indonesia

Volume 2 Number 4

Page 423-437

knowledge, skills, attitudes and behavior. These four aspects must be achieved so that the learning goals can be actualized. Therefore, the role of teachers and students is very important. In this research, the researchers only focused on investigating the students' learning development in cognitive (knowledge) aspects, because they wanted to see whether this problem solving method had an effect on students' learning outcomes, or not in understanding the language learning materials in the classroom.

The success of the teaching and learning process can be influenced by various aspects, such as teaching methods, infrastructure, learning materials, curriculum and so forth. From these various aspects, the aspect that plays an important role in the learning process is the teacher. Thus, it can be said that all the aspects should be supported basically by the teachers' competence, so the teaching and learning can be conducted successfully (Asih, 2016).

In the process of learning Indonesian language and literature, the competencies that Indonesian language teachers must have are not only the mastery of theories and materials of Indonesian language and literature, but more importantly the teacher should have competence in delivering the learning materials to the students because the main purpose of Indonesian language lessons is that the students have to be able to master the language skills (Asih, 2016).

One of the alternatives to promote the students' creativity and learning outcomes in language learning is by applying problem solving method. Indonesian language subject can be considered as one of the fun learning subjects as the teachers can motivate students to learn to communicate with fellow classmates in the class. For instance, the teachers divide the students into several groups and give them questions as the learning task, and the teacher will assess which group is the most active in completing the task that has been given, this will enable the students to compete in order to get good grades.

By using the problem solving method, students not only have argument skill, but also are able to find problem solving points. Thus, there will be no grudge against the group leader and unanswered questions anymore by the students 
Jadila: Journal of Development and Innovation

E-ISSN: 2723-6900

in Language and Literature Education

P-ISSN: 2745-9578

Publisher: Yayasan Karinosseff Muda Indonesia

Volume 2 Number 4

Page 423-437

because the problems have been successfully solved and given by the groups caused by the teacher's role in it as well (Ni L. Eka Sumiarti, et al, 2017).

Based on the preliminary observation by the researchers at the Indonesian language learning process in the second grade students of IPA class of SMA Negeri 5 Lebong, that most of the students only heard explanations from their teachers, they did not participate in arguments, when given assignments by their teachers they were less enthusiastic in answering the questions given. There needs to be improvements to improve student learning outcomes as the teachers had better really understand the methods used when they were teaching Indonesian language subject. Thus, problem solving was the right method used by teachers. By using this method, the students can improve their learning outcomes because this method is able to make students more active in the class. In this case, they can develop their argument skills as they can learn to solve problems given by the teacher in the class together argumentatively.

Based on the problems above, researchers was interested to investigate the research entitled "The Effect of Problem Solving Learning Method on Indonesian Subject Learners' Learning Outcomes: A Quasi Experimental Study the Second Grade Students of IPA Class of SMA Negeri 5 Lebong" as the learning method used by the teachers was still conventional method and the students still had low learning motivation and enthusiastic.

\section{B. Research Method}

This research was designed by using a quantitative approach with a quasiexperimental method. Quasi-experimental method can be defined as a method which uses control group and experimental group, but in this research, the control class did not have a crucial function to control the external variables fully which influenced the implementation of the experiment. It can be used when it is hard for researcher to find the control group used in the research (Sugiyono, 2019).

Research population can be defined as an area consisting of the subjects and the objects having certain quantity and characteristics set by researchers to be 
Jadila: Journal of Development and Innovation

E-ISSN: 2723-6900

in Language and Literature Education

P-ISSN: 2745-9578

Publisher: Yayasan Karinosseff Muda Indonesia

Volume 2 Number 4

Page 423-437

canvassed and drawn the conclusion (Sugiyono, 2019). Population of this research was at the second grade students of IPA classes of SMA Negeri 5 Lebong consisting of 56 students derived from IPA 1 class consisting of 28 students and IPA 2 consisting of 28 students.

Research samples can be defined as a part of the number and characteristics possessed by the population (Sugiyono, 2019). This research used a census or total sampling. Thus, the sample in this research were students from class XI IPA 1 and IPA 2 totaling 56 students. Class XI IPA 2 as the experimental class consisted of 28 students and class XI IPA 1 as the control class consisted of 28 students. Data collection techniques can be defined as the most important step in research, because the main purpose of research is to get data through tests. A test is a tool used by researchers to find out or measure something in a certain atmosphere through predetermined ways and rules (Suharsimi Arikunto, 2016). The technique of collecting data used in this study was to give pre-test and posttest to the experimental class and control class after giving the treatment. The learning outcomes that would be compared after giving treatment were the learning outcomes of the experimental class and the control class in the form of post test scores.

The validity and reliability of a research instrument must be tested before it is used. The test of the instrument was carried out outside the class that was used as a sample, the test of this instrument was carried out in class XI IPS 1 . The validity and reliability test was tested using SPSS 20 . The validity of the data in this study was about the accuracy of the Indonesian language test instrument. In order to know the validity of the Indonesian language test questions, the researchers conducted a correlation test between the scores (values) of each item with the test scores. Based on the results of the validity test, it could be seen that the number of valid test items was 25 items, while 5 items were declared invalid. Therefore, 25 items were used as post-test questions for the students, formed into questions number 1 to question number 25. Meanwhile, questions that were invalid were excluded from the student post-test questions. 
Jadila: Journal of Development and Innovation

E-ISSN: 2723-6900

in Language and Literature Education

P-ISSN: 2745-9578

Publisher: Yayasan Karinosseff Muda Indonesia

Volume 2 Number 4

Page 423-437

The reliability of the instrument test was carried out using the Alpha Cronbach method. From the reliability calculation using the SPSS version 20 application, it could be seen that the instrument compiled was reliable and could be used to obtain data, the calculation results obtained were 0.889 greater than rtable. Thus, this instrument could be declared reliable. The data of this research were analyzed through the following steps: 1) Statistical Analysis Prerequisite Test (Normality Test, Homogeneity Test, Linearity Test). To facilitate the calculation of the prerequisite test for the analysis of researchers in determining the homogeneity of the data, the researchers were assisted by SPSS version 20,2 ) Data hypothesis test, Hypothesis testing of this research was carried out by using a comparative test named the t-test.

\section{Result and Discussion}

\section{Result}

In this research, before the experiment was conducted, a pre-test was first carried out by giving the same treatment between the experimental class and the control class by the researchers. Based on the result of the pre-test, it was found that the initial abilities of students in class XI IPA 1 and XI IPA 2 had almost the same average, namely 61.28 and 62.85 . Thus, the research continued by giving treatment to class XI IPA 2 as the experimental class.

\section{a. The implementation of Experiment Process}

\section{1) The first meeting}

At this first meeting all students were present. The first activity began with the teaching and learning process, the material presented in this teaching and learning process was material about scientific work. Learning activities begin by opening the lessons, doing apperception and conditioning the students. The students were directed to open the chapter on scientific work. Moreover, the students were directed to read the material to be taught, and the researchers applied the problem-solvingbased learning method through the following steps: 
The core learning activities were conducted to explain the learning material. Preliminary activities: 1) prepare learning conditions, 2) discuss learning objectives, 3) perform apperception. Core activities: 1) present the material, 2) form small group discussions, 3) giving assignments to students, 4) students discussing the assignments given, 5) closing the class discussion. Closing activities: 1) draw conclusions, 2) provide an assessment.

\section{2) The second meeting}

The second meeting with the main discussion on learning materials regarding the systematics of scientific work. In this meeting, 28 students attended. Learning activities begin by opening the lessons, doing apperception and conditioning students. Furthermore, the researcher's core learning activities explain the learning material.

Furthermore, the researcher applied the problem solving learning method by conducting the following steps: Core learning activities were conducted by explaining scientific work. Preliminary activities: 1) prepare learning conditions, 2) discuss learning objectives, 3) perform apperception. Core activities: 1) presenting the material, 2) forming small group discussions in their respective seats, 3) giving assignments to students, 4) students discussing the assignments given, 5) closing the class discussion. Closing activities: 1) draw conclusions, 2) provide an assessment.

\section{3) The third meeting}

The third meeting discussed the linguistic material of scientific papers. Learning activities begin by opening the lessons, doing apperception and conditioning the students. Furthermore, the researchers' core learning activities were to the learning material. Furthermore, the researchers applied the problem solving learning method (problem solving) through the following steps: 
The core learning activities related to the explanation of scientific work. Preliminary activities: 1) prepare learning conditions, 2) discuss learning objectives, 3) perform apperception. Core activities: 1) presenting the material, 2) forming small group discussions in their respective seats, 3) giving assignments to students, 4) students discussing the assignments given, 5) closing the class discussion. Closing activities: 1) draw conclusions, 2) provide an assessment.

\section{b. Test Score}

After learning in class XII IPA 2 (experimental class) by implementing the problem solving learning method (problem solving) and class XI IPA 1 (control class) by implementing the conventional learning method for 3 meetings. The post-test was carried out to find out the learning outcomes of the experiment activities. This data was obtained from the results of the students' tests after learning Indonesian using problem solving learning method. It could be concluded that the Indonesian language learning outcomes of 28 students after being given an implementation using problem solving learning method, the average value was 77.85 . Furthermore, the results of the post-test of students in class XI IPA 1 (control class), it was known that the test scores of 28 students in the control class obtained an average score of 67.71 .

If it was seen from the results of the average post test scores between the experimental class that had been given treatment using problem solving method and the control class that used conventional methods, the results of the experimental class gained much higher than the value before the implementation of the learning method which was 77.85 while the value obtained by the control class that was 67.71 .

\section{c. Pre-Requirements Test}

\section{1) Normality test}


Testing the normality of the data was intended to find out that the research came from the data that were normally distributed. Normal criteria could be accepted if the results of the significance test for a significance level show 0.05 , so if the significance obtained is greater than 0.05 ( $\mathrm{sig}>0.05$ ), then the data analyzed is normally distributed. Meanwhile, if the significance obtained is less than 0.05 ( $\mathrm{sig}<0.05$ ) then the research data are not normally distributed.

Tabel 4.5

Test of Normality

\begin{tabular}{|c|c|c|c|c|c|c|c|}
\hline \multirow{2}{*}{\multicolumn{2}{|c|}{ Kelas }} & \multicolumn{3}{|c|}{ Kolmogorov-Smirnov $^{\mathrm{a}}$} & \multicolumn{3}{|c|}{ Shapiro-Wilk } \\
\hline & & \multirow{2}{*}{$\begin{array}{c}\text { Statistic } \\
, 129\end{array}$} & \multirow{2}{*}{$\begin{array}{l}\text { Df } \\
28\end{array}$} & \multirow{2}{*}{$\begin{array}{l}\text { Sig. } \\
200^{*}\end{array}$} & \multirow{2}{*}{$\begin{array}{c}\text { Statistic } \\
, 966\end{array}$} & \multirow{2}{*}{$\begin{array}{l}\mathrm{df} \\
28\end{array}$} & \multirow{2}{*}{$\begin{array}{r}\text { Sig. } \\
, 488\end{array}$} \\
\hline Hasil & PreTest & & & & & & \\
\hline Belajar & Eksperime & & & & & & \\
\hline \multirow[t]{8}{*}{ Siswa } & $\mathrm{n}$ & & & & & & \\
\hline & PostTest & , 198 & 28 & ,074 & ,805 & 28 & ,123 \\
\hline & Eksperime & & & & & & \\
\hline & $\mathrm{n}$ & & & & & & \\
\hline & PreTest & , 187 & 28 & .200 & ,929 & 28 & ,058 \\
\hline & Kontrol & & & & & & \\
\hline & PostTest & ,261 & 28 & .079 & ,735 & 28 & ,000 \\
\hline & Kontrol & & & & & & \\
\hline
\end{tabular}

Seen from the table above, it could be seen that the significance value of each variable showed a value greater than 0.05 , it could be concluded tha the data in the test was normally distributed.

\section{2) Test of Homogeneity of Variance}


The homogeneity test was intended to show that two or more groups of sample data come from populations that had the same variation. The homogeneity test criteria were accepted if the results of the significance test for the significance level were 0.05. If the significance obtained was more than $>\alpha$, so the variance of each sample was the same (homogeneous). Meanwhile, if the obtained significance $<\alpha$, so the variation of each sample was not the same (not homogeneous).

Table 4.6

Test of Homogeneity of Variance

\begin{tabular}{|c|c|c|c|}
\hline Levene Statistic & df1 & df2 & Sig. \\
\hline, 028 & 1 & 54 &, 867 \\
\hline
\end{tabular}

Seen from the table above, it could be seen that the significance value of each variable was greater than the value of 0.05 . As for the significance value obtained 0.867 which was greater than 0.05 , it could be concluded that the data tested had the same variation in each sample (homogeneous).

\section{3) Hypothesis Test}

The researcher conducted a t-test. T-test analysis was performed using SPSS 20.00. The t-test was used to determine whether there was an effect of problem solving learning methods on student learning outcomes in Indonesian class XI science subjects at SMA Negeri 5 Lebong. The statistical hypotheses tested in this research were:

a) $\mathrm{Ha}$ : There was an effect of problem solving learning method towards Indonesian subject learners' learning outcomes at the second grade students of SMA Negeri 5 Lebong 
b) Ho: There was no effect of problem solving learning method towards Indonesian subject learners' learning outcomes at the second grade students of SMA Negeri 5 Lebong.

If the value of $t_{\text {count }}>t_{\text {table }}$, Ha could be accepted which meant that there was the effect of problem solving learning methods on student learning outcomes in Indonesian class XI science subjects at SMA Negeri 5 Lebong. Meanwhile, if the value of $t_{\text {count }}<t_{\text {table }}$, Ha was rejected and $\mathrm{HO}$ could be accepted which meant that there was no effect of problem solving learning methods on student learning outcomes in Indonesian class XI science subjects at SMA Negeri 5 Lebong. The following are the results of hypothesis testing that had been carried out by the researchers using SPSS 20.00 program:

Tabel 4.7

Paired Samples Test

\begin{tabular}{|c|c|c|c|c|c|c|c|c|c|}
\hline & \multicolumn{5}{|c|}{ Paired Differences } & \multirow[b]{3}{*}{$\mathrm{T}$} & \multirow{3}{*}{$\begin{array}{l}\mathrm{D} \\
\mathrm{f}\end{array}$} & \multirow{3}{*}{$\begin{array}{l}\mathrm{S} \\
\mathrm{i} \\
\mathrm{g}\end{array}$} \\
\hline & & \multirow[b]{2}{*}{ Mean } & \multirow{2}{*}{$\begin{array}{l}\text { Std. } \\
\text { Deviati } \\
\text { on }\end{array}$} & \multirow{2}{*}{$\begin{array}{l}\text { Std. } \\
\text { Error } \\
\text { Mean }\end{array}$} & \multicolumn{2}{|c|}{$\begin{array}{l}95 \% \text { Confidence } \\
\text { Interval of the } \\
\text { Difference }\end{array}$} & & & \\
\hline & & & & & Lower & Upper & & & \\
\hline Pair & Pre- & 16,571 & 11,033 & 2,0854 & 20,850 & 12,293 & 7,9 & 27 & ,00 \\
\hline 1 & Test & & & & & & 47 & & 0 \\
\hline & $\begin{array}{l}\text { Post- } \\
\text { Test }\end{array}$ & & & & & & & & \\
\hline
\end{tabular}

Seen from the table above, the results of the t-test analysis showed that the value of $t_{\text {count }}=7.947>t_{\text {table }}=2.048$ with the significance level $95 \%$ with $\alpha=0,05$. Thus, it could be stated that the alternative hypothesis Ha could be accepted and the null hypothesis $\mathrm{H} 0$ was rejected which meant that there was an influence of problem solving learning method on student learning 
Jadila: Journal of Development and Innovation

E-ISSN: 2723-6900

in Language and Literature Education

P-ISSN: 2745-9578

Publisher: Yayasan Karinosseff Muda Indonesia

Volume 2 Number 4

Page 423-437

outcomes in Indonesian language subjects in class XI science at SMA Negeri

5 Lebong. Furthermore, the results of the correlation between the two variables obtained the correlation value as follows:

Tabel 4.8

Correlations

\begin{tabular}{|l|l|c|c|}
\hline \multicolumn{2}{|c|}{} & Control Class & Experiment Class \\
\hline \multirow{4}{*}{ Control Class } & Pearson Correlation & 1 & .201 \\
\cline { 2 - 4 } & Sig. (2-tailed) & & .305 \\
\cline { 2 - 4 } & $\mathrm{N}$ & 28 & 28 \\
\hline \multirow{4}{*}{ Experiment Class } & Pearson Correlation & .201 & 1 \\
\cline { 2 - 4 } & Sig. (2-tailed) & .305 & \\
\cline { 2 - 4 } & $\mathrm{N}$ & 28 & 28 \\
\hline
\end{tabular}

Based on the table above, the correlation value was 0.305 . Furthermore, the calculation of the coefficient of determination would be carried out using the following formula:

$\mathrm{Kd}=\mathrm{r} 2 \times 100 \%$

$\mathrm{Kd}=0.305 \times 100 \%$

$\mathrm{Kd}=9.30 \%$

It could be deemed that the implementation of problem solving learning method on student learning outcomes in Indonesian subjects was $9.30 \%$ and the rest was determined by other variables.

\section{Discussion}

The problem solving model is one of the teaching models used by teachers in the learning process activities. This model can stimulate

students in thinking that starts from looking for data to formulating conclusions so that students can take meaning from learning activities. So, it can be concluded that problem solving is a skill that includes the ability to seek information, analyze situations, and identify problems with the aim of 
generating alternatives so that they can take a decision action to achieve the target (Aris Shoimin, 2013).

Problem solving is a type of learning that focuses on teaching and problem solving skills followed by skill strengthening. In this case, problem solving learning has the potential to train students to think creatively in dealing with various group problems. Students learn on their own to identify causes and alternatives to solve the problem (Jauhar and Nurdin, 2017).

Problem solving method is a teaching method used by teachers to encourage students to seek and find and solve problems. The knowledge gained by learning problem solving methods will last a long time, have a better transfer effect and increase students' ability to think freely. In general, learning this problem solving method trains cognitive skills to find and solve problems without the help of others. In addition, discovery learning arouses students' curiosity, motivates them to work until they find answers (Pristiwanto, 2016).

Based on the results of research and data analysis that had been carried out, it could be seen that there was the effect of problem solving learning methods on student learning outcomes in Indonesian class XI science subjects at SMA Negeri 5 Lebong. This could be seen from the pre-test and post-test scores. Based on the test results in the experimental class (class XII IPA 2), an average score of 77.85 was obtained, while the control class obtained an average value of 67.71 .

Based on the research data, it could be seen that the average student learning outcomes in the experimental class were higher than those of the control class. This showed that there was an effect of problem solving learning methods on learning outcomes of students in Indonesian class XI IPA at SMA Negeri 5 Lebong. Furthermore, the results of the t-test also showed that problem solving learning methods had an influence on student learning outcomes in Indonesian class XI science subjects at SMA Negeri 5 Lebong. Based on the $\mathrm{t}$-test, the value of $\mathrm{t}_{\text {count }}=7.947>\mathrm{t}_{\text {table }}=2.048$ with a 

significance level of $95 \%$ with $\alpha=0.05$. Thus, the working hypothesis in the research stating that there was an effect of problem solving method towards Indonesian subject learners' learning outcomes at the second grade students of SMA Negeri 5 Lebong could be accepted and the null hypothesis stating that there was no effect of problem solving learning methods towards Indonesian subject learners' learning outcomes at the second grade students of SMA Negeri 5 Lebong had been rejected.

Before applying the problem solving learning method, students were less active in class and they also paid less attention to the teacher when explaining the lesson. In addition, the teacher did not involve students during the learning process so that the material presented was not conveyed properly to the students. It caused the students' scores to be low, while after the implementation of problem solving learning method in the experimental class the learning process was more active and more focused, enthusiastic. The student learning increased when teachers provided their space to discuss solving problems that existed in the learning being taught. By implementing this problem solving learning method, the rest of the students were able to find opportunities to express their opinions and accepted the other people's opinions so that this enabled the class atmosphere to come alive.

Based on the results of observations made in 3 meetings, there were differences in learning activities between the two classes. Experimental class students each indicator and descriptor became higher, especially on indicators of hard work and active in the learning process. It could be seen that the experimental class played an active role in the learning process by using test sheets. In the control class, there were several indicators of student learning that did not appear, such as the indicators of independence, students looked silent and only a few were diligent in solving problems in ongoing learning materials because at the time of discussion students were not motivated to ask the teacher and other groups so they tended to be passive and it was also seen that each group still relied on only one friend. Problem solving learning 
methods had a significant influence on student learning outcomes. This learning method had an influence on the experimental class students showing a good influence in the experimental class where the experimental class obtained higher student learning outcomes than those of the control class.

\section{Conclusion}

Based on the result and discussion of this research, it can be concluded that problem solving learning methods had the influential effect towards Indonesian subject learners' learning outcomes at the second grade students of SMA Negeri 5 Lebong. By implementing this method, the students were asked to make group discussions to solve the problems given by the teachers. It could be seen that $t_{\text {hitung }}=7,947>t_{\text {tabel }}=2,048$ with the significance level $0,05 \%$. The alternative hypothesis proved that the effect of problem solving on the Indonesian learners' learning outcomes at the second grade students of IPA Class of SMA Negeri 5 Lebong was acceptable.

\section{References}

Arikunto, S. (2016). Dasar-dasar Evaluasi Pendidikan, Jakarta: Bumi Aksara. Asih. (2016). Strategi Pembelajaran Bahasa Indonesia. Bandung:Pusaka Setia.

Eka, N, S. (2017). Penggunaan Metode Problem Solving Oleh Guru Bahasa Indonesia Dalam Pembelajaran Debat Di Kelas X SMA Negeri 1 Sawan $e$ Journal Jurusan Pendidikan Bahasa dan Sastra Indonesia, 7(2), 2.

Hartini, R. (2019). Strategi Belajar Mengajar. Bengkulu.

Ruslan, R. (2010). Metode Penelitian Public, Relations, dan Komunikasi. Jakarta: PT Raja Grafindo Persada.

Shoimin, A. (2014). 68 Model Pembelajaran Inovatif Dalam Kurikulum 2013. Yogyakarta: Ar Ruzz Media.

Sugiyono. (2014). Statistika Untuk Penelitian. Bandung: Alfabeta.

Sugiyono. (2019). Metode Penelitian Kuantitatif, Kualitatif, dan R\&D. Yogyakarta: Alfabeta. 